\title{
The Dynamics of Urban Public Space Perception in the New Normal Era
}

\section{Yordan Kristanto Dewangga1, Sita Yuliastuti Amijaya ${ }^{2}$, Hoseo Viadolorosa ${ }^{3}$}

\author{
'Student of Magister of Architecture, Duta Wacana Christian University, \\ Yogyakarta, Indonesia \\ ${ }^{2}$ Lecture of Magister of Architecture, Duta Wacana Christian University, \\ Yogyakarta, Indonesia \\ ${ }^{3}$ Student of the Bachelor of Architecture, Duta Wacana Christian University, \\ Yogyakarta, Indonesia
}

\author{
Article History \\ Received : 30 November 2020 \\ Accepted : 02 March 2021 \\ Published : 24 April 2021
}

\begin{abstract}
The coronavirus pandemic or Covid-19 has happened in several countries, including Indonesia. This condition has an impact not only on public health but also on all sectors. Yogyakarta, a province in Indonesia, receives the impact of this pandemic, especially the Malioboro as a famous public area in the city. The Malioboro area, as an urban public space, becomes quieter due to the coronavirus pandemic. The new normal policy, which the government implemented through the adaptation of new habits, gradually bringing back the activities in the Malioboro area. Health protocols to maintain social distancing keep on encouraged with direct and written persuasive methods. The purpose of this study is to explore people's perceptions of urban public spaces in the new normal era in Malioboro. The method used was conducting a direct survey in Malioboro and giving a closed questionnaire online to the public. The discussion was performed by examining the results of a closed questionnaire with the current situation in Malioboro. The conclusions obtained that the community has received information to maintain social distancing. However, many people ignore the health protocols so that no difference with the situation before the pandemic. This condition does not change the spatial patterns and layouts related to space at the public scale and the distance of social interactions.
\end{abstract}

Keywords: Covid-19; public spaces; social distancing; social interaction.

\section{Introduction}

The Corona Virus pandemic or Covid-19 has hit several countries in the world, including Indonesia. This pandemic situation has an impact not only on public health but also on all sectors. In previous normal times, local governments in many cities competed to obtain various attributes and advantages embedded in their cities. These attributes can be in the form of environmental carrying capacity, ability to survive, competitiveness, and sustainability. But in certain situations and times of crisis like today, a city is required to function properly for its citizens.

Correspondence:Yordan K. Dewangga

Duta Wacana Christian University, Yogyakarta, Indonesia

E-mail: yordankristantodewangga@gmail.com
Intensive policy coordination and strategy are needed to create well-functioning cities inclusive, healthy, resilient, and sustainable. To reduce the transmission of the coronavirus and protect individuals and society's health, health protocols were implemented to limit the use of public spaces with social distancing policies.

Yogyakarta, as one of the tourist destinations in Indonesia, has a well-known public space not only for the people of Yogyakarta but also for people from outside the region (Nisa and Haryanto, 2014, p. 934), namely the Malioboro Street area (after this referred to as Malioboro). As a public space, Malioboro is a place for social interaction, buying and selling transactions, and attractions that are always crowded with tourists almost every day. But Malioboro, which is usually busy, is now quieter due to the Covid-19 pandemic. Health protocols to maintain social distancing, avoid 
The Dynamics of Urban Public Space Perception in the New Normal Era

Yordan Kristanto Dewangga, Sita Yuliastuti Amijaya, Hoseo Viadolorosa crowd, stay at home, and avoid public places have caused activity in Malioboro to become quieter, so there is not much activity happening in this area (Figure 1).

Figure 1. The quiet Malioboro area due to the corona virus pandemic.

Source:https://news.detik.com/berita-jawatengah/d-4954252/malioboro-yogya-suwung-gegaracorona/1

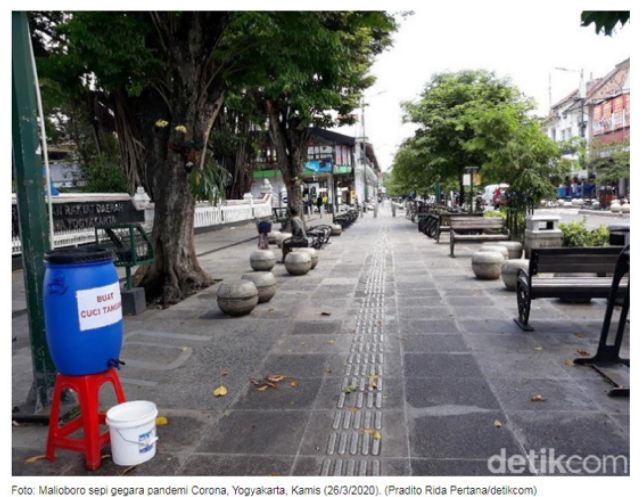

The government issued a new normal policy by adopting new habits. Doubts arise regarding the adoption of this new habit, will Malioboro as an urban public space return to what it was before the pandemic? What dynamics might the longterm impact of the Covid-19 pandemic have on social functioning and relationships in the public sphere once these restrictions are lifted? The depth and extent of the transformation are unclear, especially concerning the design, use, and perception of public space in the future.

This study aims to highlight issues that have emerged in the new normal era after the Covid-19 pandemic, the community's social perceptions towards the application of new habits, and the possible changes in interaction patterns in the design of urban public spaces. There is a possibility that the Covid-19 crisis could fundamentally become a crisis that changes the relationship between urban users of public spaces and public spaces as a "place". This study will measure the initial process of community understanding of social distancing or physical distancing. In addition, this study documents individuals and communities' ability to exercise social distancing associated with activities in public spaces and changes in social perceptions related to interactions between individuals in public spaces.
This research raises the dynamics of issues that arise related to the possibility of implementing a new normal after the Covid-19 emergency response period, especially in Malioboro and its relation to the form of interaction and design of urban public spaces. Besides, this research wants to determine the public's understanding of changes in urban public spaces' perception and social expression.

\section{Methodology}

This research uses a qualitative method based on the phenomenon of reducing activity in urban open spaces, especially in the Malioboro street area due to the coronavirus. The Malioboro area, which on normal days is filled with activities such as walking, sitting around, taking selfies, performing art music, and buying and selling transactions, is now quieter. This happened due to a government policy to stay at home and avoid crowded places or doing the social distancing to prevent the spread of the coronavirus.

The theory used to discuss this phenomenon is the theory of public space and its supporting elements. The supporting elements of public space include street furniture and social interactions that happen on it.

The research location is in the Malioboro street area, starting from the railroad tracks of the Tugu train station to the zero kilometre area in the city centre. The reason for choosing this location is because it forms a single road axis and is a public space that consists of various activities so that it is always crowded with visitors on weekdays. The activities carried out by the community at this location include walking, sitting around, taking selfies, buying and selling transactions, seeing musical group attractions, and so on while enjoying the atmosphere of the Malioboro area, which is unique because of its architecture of shops, including the pedestrian lane with renovated street furniture, increase the comfort of visitors who are active in Malioboro.

Data collection used a closed online questionnaire method which was filled in by 153 respondents. The respondents were randomly chosen who represented citizen who lives in Yogyakarta or had lived in Yogyakarta. 


\section{Literature Review}

According to the World Health Organization $(\mathrm{WHO})^{1}$, Covid-19 is an infectious disease caused by the coronavirus. This virus attacks the human respiratory system and can worsen if it affects the elderly with respiratory problems, diabetes, and cancer. This virus can be transmitted easily through the nose, coughing, or sneezing. Until now, there has not been found a specific drug or treatment method to cure this disease.

Maintaining social distancing is one of the most recommended ways by the government to reduce this virus's spread. According to the Regulation of the Minister of Health of the Republic of Indonesia Number 9 of 2020 concerning Guidelines for Large-Scale Social Restrictions, to maintain social distancing, it is carried out by vacationing the workplace, limiting activities in public places or facilities, and limiting social and cultural activities.

Reporting from the WHO website page ${ }^{2}$, efforts to maintain social distancing can be made by maintaining a minimum distance of 1 meter from other people, avoiding crowds, covering nose and mouth with arms or tissues when coughing or sneezing, staying at home, and wearing a mask if necessary to go out of the house. This is important to do in the new normal era like today so that people do their usual activities and adapt to new habits that are in accordance with health protocols.

\section{Social Distancing}

Theories about distance and space that studies human perceptions of space are called Proxemic (Hall in Mulyana, 2005). In daily interactions, such as when using public facilities or in a crowd, humans still have their own space, meaning that humans create distance or space. Humans function to create distance or space among others is to create a sense of security, facilitate communication, establish intimacy, and reduce potential threats. There are four distance zones, namely (1) Intimate Distance $(<0.5$ meters). This prerequisite is the existence of emotions between two or more people. (2) Personal Distance (0.5 - 1.5 meters), this distance is a personal distance, where someone can still hold hands or discuss personal problems. (3) Social Distance (1.5 - 3.0 meters) is also called psychological distance, where a person can feel anxious if others enter their boundaries. At this distance, someone can easily join or leave discussions or chats with those around them. (4) Public Distance (> 3.0 meters), this distance is often used in public places. Usually, there is no deep exchange of information (Mulyana, 2005),.

Hantono (2019) wrote that a person's behaviour in responding to a spatial space could be influenced by several factors such as culture, age, gender, and others. Hantono (2019) adds that someone's personal space is dynamic and can change to feel anxious if someone else enters their personal space. The pandemic may limit someone's ability to develop new relationships, especially among strangers (Honey-Roses et al, 2020, p. 11). From the opinion above and current conditions (Covid-19 pandemic), health factors can also affect a person's social distance interacting in public spaces.

\section{Public Space}

Urban public space is an important element of a city's liveability (Lennard in Rossini and Nervino, 2019, p. 64). Public space is needed to create a safe, viable, and sustainable urban environment (Schmidt and Nemeth, 2010, p. 454). A well maintained, healthy, and safe public space can make a city become an attractive place to live and work (Andersson, 2016, p. 5). Public space must be used for various activities, be used by the general public from various backgrounds, have links with social contexts (Illiyin and Idajati, 2015), and can be used as a meeting location and a place for joint activities (Wardhani, 2018). Apart from being a place for activities and socializing, public space also has benefits in improving humans' economy and health (Pratiwi, 2016, p. 64).

Public space based on its shape can be divided into the street, e.g. road corridor and square (Mulyandari, 2011). Nasution and Zahrah (2017) also argue that public spaces can be in the form of squares, gardens, parks, circulation paths, and space between buildings. The existence of street furniture can support the

\footnotetext{
${ }^{1}$ https://www.who.int/health-topics/coronavirus\#tab=tab_1, accessed 2 June 2020

${ }^{2}$ https://www.who.int/emergencies/diseases/novel-coronavirus-2019/advice-for-public, accessed 2 June 2020
} 
The Dynamics of Urban Public Space Perception in the New Normal Era

Yordan Kristanto Dewangga, Sita Yuliastuti Amijaya, Hoseo Viadolorosa existence of public space. Street furniture is the road landscape element to support comfort, pleasure, information, circulation control, and protection of road users. Street furniture elements should be able to reflect and blend with the character of the local environment (Saifuddin and Qomarun, 2019).

Manurung (2018) adds if the public space should be a space for community activity and socialization, relieve fatigue, and play and interact with all city residents. According to Manurung (2018), the public space of a city cannot be equated with other cities, elements of local culture, lifestyle, and social patterns are unique concepts of public space used by each city. The quality of public spaces' in a city can be seen from these public spaces performance in providing comfort for its users (Octarino and Kristiadi, 2019, p. 6).

\section{Social Interaction}

The existence of public space cannot be separated from the social interactions of its users. Public spaces that are identical to various social activities and interactions should be enjoyed by everyone without any restrictions (Rahmiati, 2017, p. 1). According to Gerungan (2010), social interaction is a relationship between two or more individuals where one behaviour affects and changes the other's behaviour, and vice versa. Social interactions can be influenced by social situations such as togetherness. A togetherness situation is when people who do not know each other get together, and the social interactions between them are not very deep. The most important thing in this situation is that they do not have such deep social interactions, but they are in one place to fulfill a common good. An example is the people gathered in a market. Their presence in the market is not for deep social interaction but because of common interests, such as shopping (Gerungan, 2010).

The activities of users of public spaces can contain four elements, namely (a) actual activities such as walking, eating, etc., (b) ways of doing such as: walking on the sidewalk, eating at home, and others, (c) additional activities such as: walking while looking at shop windows, e.g. window shopping, and (d) experiencing activities and the environment (Saifuddin and Qomarun, 2019).

\section{Result and Discussions}

Malioboro is a well-known public space for the people of Yogyakarta and people from outside the region. It is evident from the closed online questionnaire filled in by 153 respondents that $99.3 \%$ knew about the Malioboro road area, especially from the railroad tracks to the zero-kilometer point. As already stated that the selected respondents are those who live in Yogyakarta or have lived in Yogyakarta. It is obtained data that respondents come from various regions, such as Lampung, Makassar, Toraja, Ambon, and Kupang. This shows that Malioboro is a distinctive public space and is open not only to Yogyakarta residents but also to people from outside the region.

Based on the questionnaire results, those who have visited Malioboro always take the time to come back to visit this area even though at different times, some are every month, every 3-6 months, every year, or every holiday season arrives. Visitor comes to this area with various purposes, from shopping to taking a walk or sitting around enjoying the atmosphere of Malioboro. The following is a photo of the Malioboro Street area with various activities carried out by both visitors and business people in Malioboro (Figure 2).

Figure 2. Night music attractions are one of the interesting activities in the Malioboro street area.

Source: Dewangga Documentation, 2019.

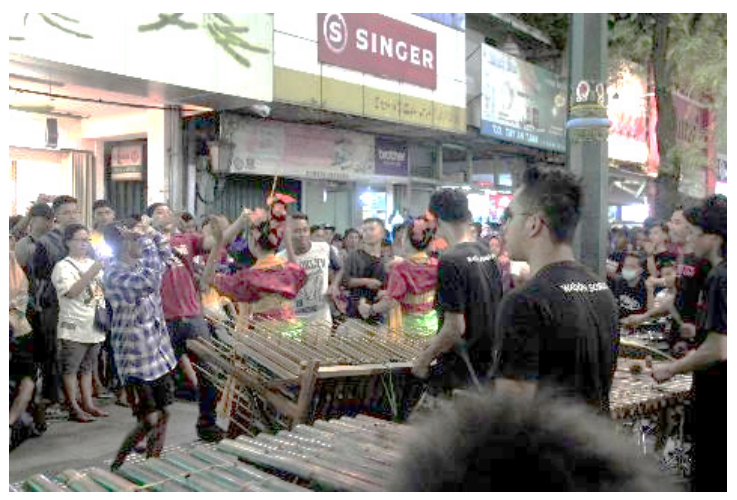

As a public space, Malioboro is inseparable from the architectural elements that form it, such as old buildings that are still standing and street furniture along Malioboro. This is evidenced by the questionnaire results, where $54.9 \%$ of respondents answered that architectural elements are the most interesting things in the Malioboro street area. The existence of street furniture elements, such 
as benches or chairs, greatly supports visitors' comfort who are active in this area. Those who are tired of walking can rest on the benches provided. Also, the Malioboro street signboard is an element of street furniture often used as a photo object for visitors (Figure 3).

Figure 3. Street furniture in Malioboro.

Source: Dewangga Documentation, 2019.

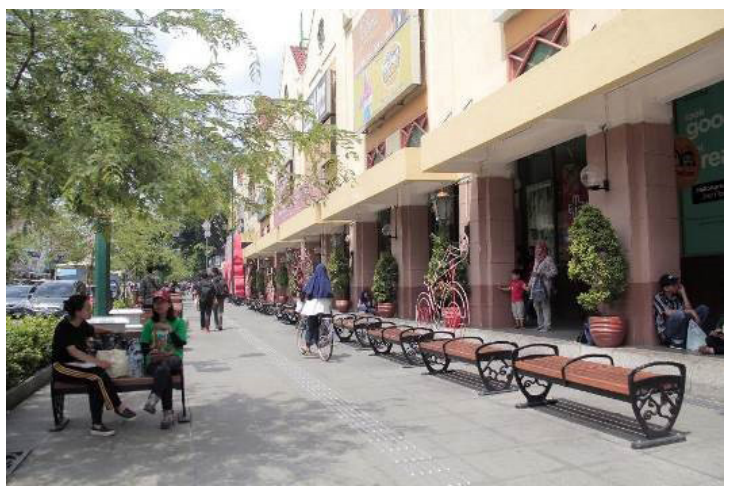

The existence of Malioboro as a public space is in accordance with Illiyin and Idajati (2015) opinion, where this area can accommodate various community activities both individually and in groups, and can become a place for people to socialize, seek entertainment, and release fatigue with socio-cultural distinctiveness (Manurung, 2018) in Malioboro.

Since the coronavirus pandemic hit Yogyakarta in mid-March 2020, activity in the Malioboro street area has been quiet. This condition is in contrast to the condition of Malioboro in the time before the pandemic. Not many people have activities in this area and business actors who have not opened many stalls/kiosks. Pedicab and horse cart transportation service providers who are often found parking their vehicles on the side of the road are now rarely seen (Figure 4).

This condition impacts the social distancing policy issued by the Government to prevent the spread of the Covid-19 virus. With the policy to stay at home, automatically activities in public spaces will also stop. Of the 153 respondents, $98.7 \%$ have known social distancing and social distancing benefits (98.7\%). According to the questionnaire conducted, $60.1 \%$ (92 people) agreed that social distancing reduces their comfort in interacting with others, while $27.5 \%$ (42 people) of respondents did not feel social distancing policies reduce their comfort in social interaction. However, 93.5\% (143 people) agreed to do social distancing in public spaces, meaning that respondents had the awareness to maintain social distancing when in public spaces.

The Malioboro street area as a public space is synonymous with crowds. The online questionnaire results also stated that $69.9 \%$ (107 people) of respondents agreed that public spaces were identical to huddling human activities. However, $71.2 \%$ (109 people) of respondents could still enjoy freedom in public spaces without having to crowd and not reduce their comfort in social interaction in public spaces (100 respondents).

With the new normal policy, activities in public spaces, especially in the Malioboro street area, are slowly recovering with health protocols that must be implemented. This is certainly a positive thing for business actors in the Malioboro road area and for people who miss activities in the Malioboro street area. From the questionnaire results, 84.3\% (129 people) agreed that doing activities in public spaces is fun. This is in accordance with Manurung (2018) opinion, which states that the function of public space is not only a place for social interaction but also as a place for entertainment and relieving fatigue.

Figure 4. The parking area for pedicabs/ horse carts and street vendors with low activity.

Source: Dewangga Documentation, 2020.

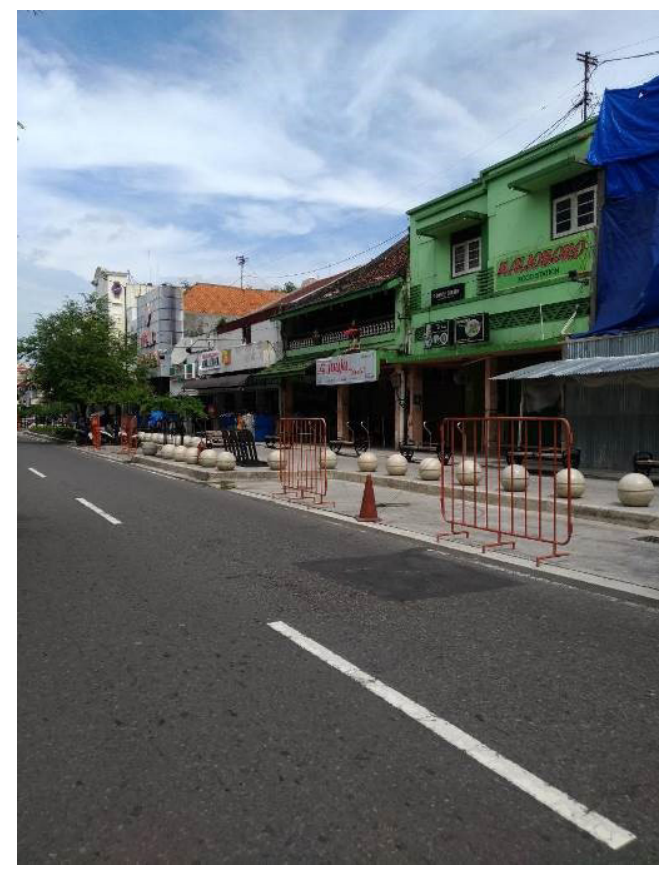


The Dynamics of Urban Public Space Perception in the New Normal Era

Yordan Kristanto Dewangga, Sita Yuliastuti Amijaya, Hoseo Viadolorosa
Now the Malioboro road area has begun to be reorganized to anticipate the spread of the coronavirus. Various methods have been applied, including placing the sinks at 40 points, 20 points on the east side of the pedestrian path and 20 points on the west side of the pedestrian path. This handwashing place is not only provided by the government but also by business actors (Figure 5 ).

Figure 5. Handwashing facilities provided by the government.

Source: Dewangga Documentation, 2020.

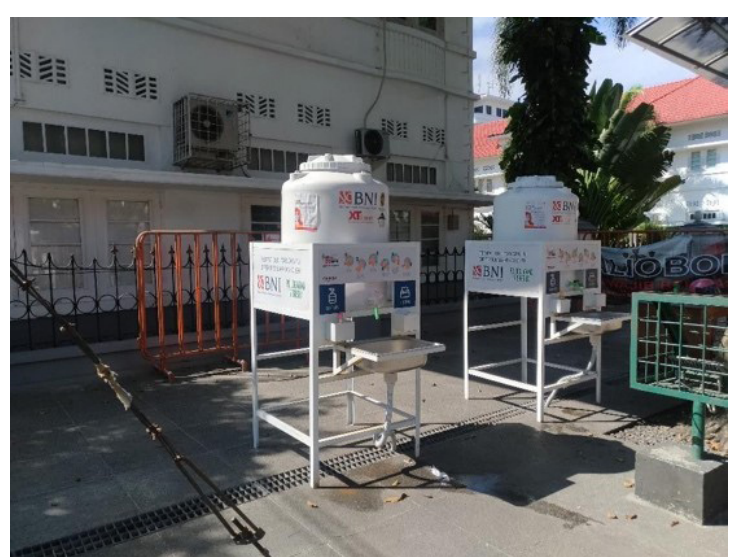

In addition to providing handwashing facilities, another method used to monitor active people in this area is by dividing the Malioboro area into five zones. The first zone starts from the Inna Malioboro hotel to Malioboro Mall. The second zone is from Malioboro Mall to Mutiara Hotel, the third zone from Transjogja 2 - Suryatmajan Bus Stop, zone four from Suryatmajan - Pabringan, and zone five from Pabringan - Zero Kilometer Point. In each zone, officers who check body temperature and visitors are asked to fill in data via barcode scans in each zone's arrival area (Figure 6). Several security guards were deployed in several places to supervise and advise people who are active in this area. Text and graphic of the health protocols are also placed in several places to remind visitors (Figure 7). Some seats have also been provided with ropes to remind people about social distancing restrictions.

Various efforts have been made by the Government to remind people who are active in the Malioboro street area always to keep their distance, even though the results are not directly proportional to what is expected. Based on the results of observations carried out on July 5, 2020, at 10:00 WIB, there are still many people who ignore the health protocols to maintain social distancing. This can be seen from the many people who are clustered and sitting close to each other (Figure 8). Even though the majority of visitors have worn masks, the call to distance themselves is ignored. Even some of the seats that had been given ropes were damaged by the community who ignored the health protocols (Figure 9).

Figure 6. Monitoring points in Zone 1 before visitors enter the Malioboro area.

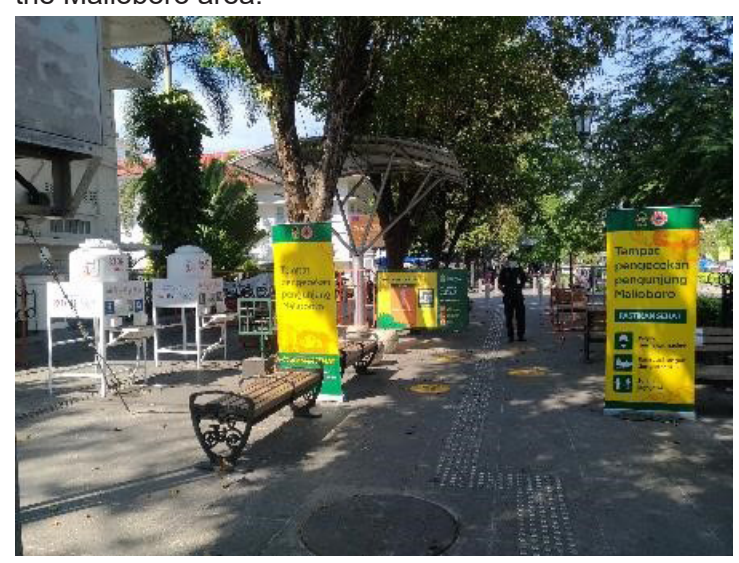

Figure 7. A health protocols information in the form of writing or graphics placed on the pedestrian path. Source: Dewangga Documentation, 2020.
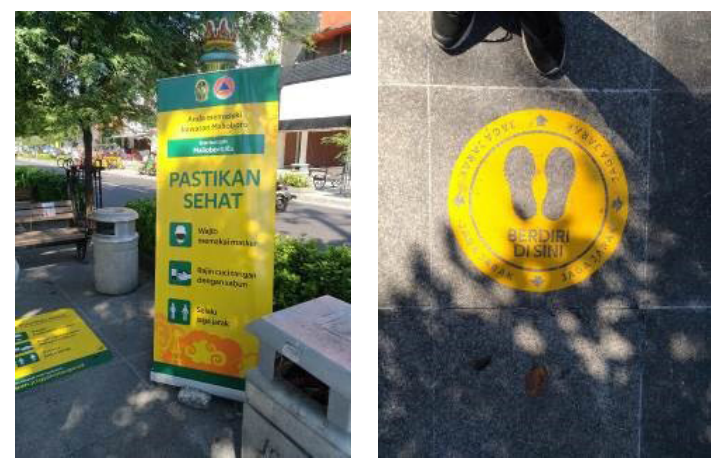

Figure 8. The call for distancing is ignored. Three people use one bench.

Source: Dewangga Documentation, 2020.

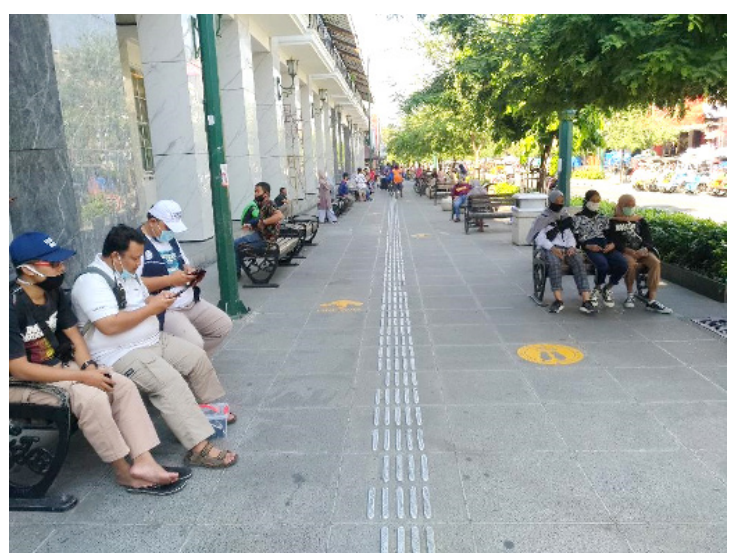


Figure 9. Seats with orange rope as a barrier, damaged condition (left).

Source: Dewangga Documentation, 2020

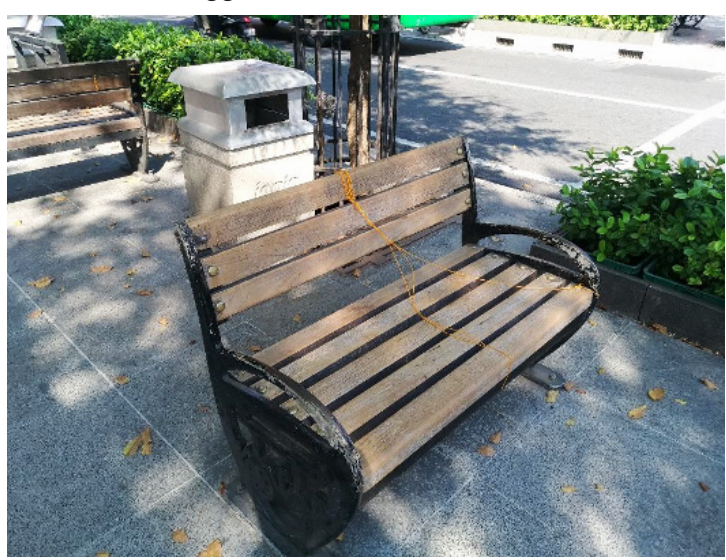

When night falls, conditions in Malioboro are getting denser in this new normal era. Based on the results of an online questionnaire, $59.5 \%$ (91 people) of respondents stated that they chose to visit Malioboro in the afternoon until evening. When observations were made on Sunday, July 12, 2020, at 19.0021.00 , it was seen that this area was getting denser with active people. Health protocols to maintain distance given by officers and written warnings are no longer valid, even though most people still wear masks when doing activities in the Malioboro area. Based on observations, it is also known that if many people are reluctant to keep their distance according to regulations (Figure 10), the community has also ignored the call to walk in one direction. Activities in the Malioboro area at night feel back to normal, even though in the new normal era (Figure 11).

Figure 10. The neglected call for distancing Source: Dewangga Documentation, 2020.

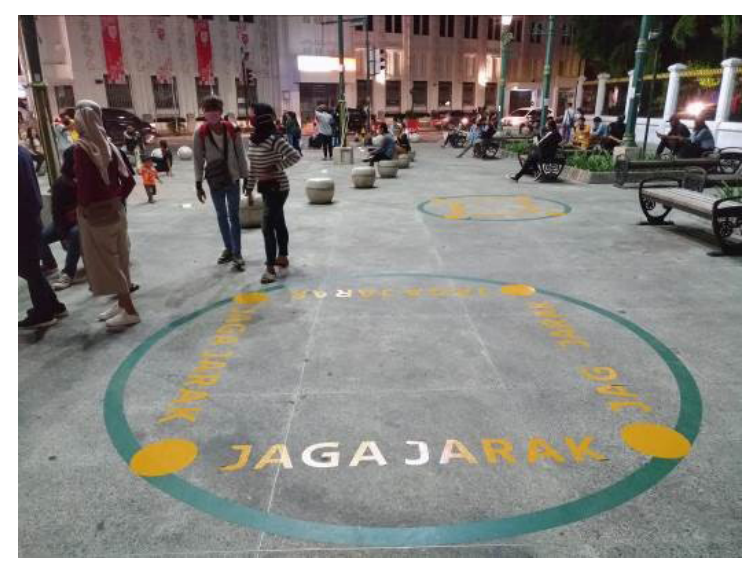

Figure 11. Zero kilometre area, which is busy with community activities.

Source: Dewangga Documentation, 2020.

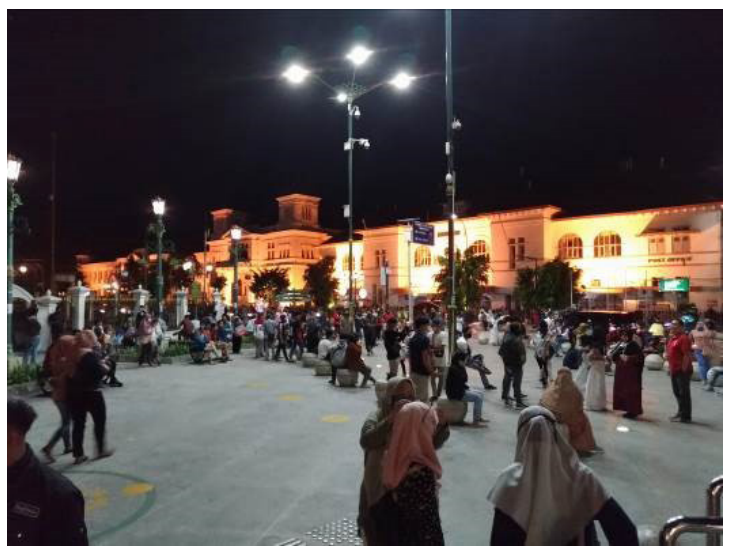

The presence of officers in the field is not able to control people's behaviour in public space. During the observation, it was very often to see several officers who chose not to reprimand the community. Some zones that were monitoring points were also not properly monitored, so that there were visitors who were not controlled (Figure 12). There were even zones where there were no officers on duty (Figure 13).

Figure 12. Officers who do not remind the public to keep their distance.

Source: Dewangga Documentation, 2020.

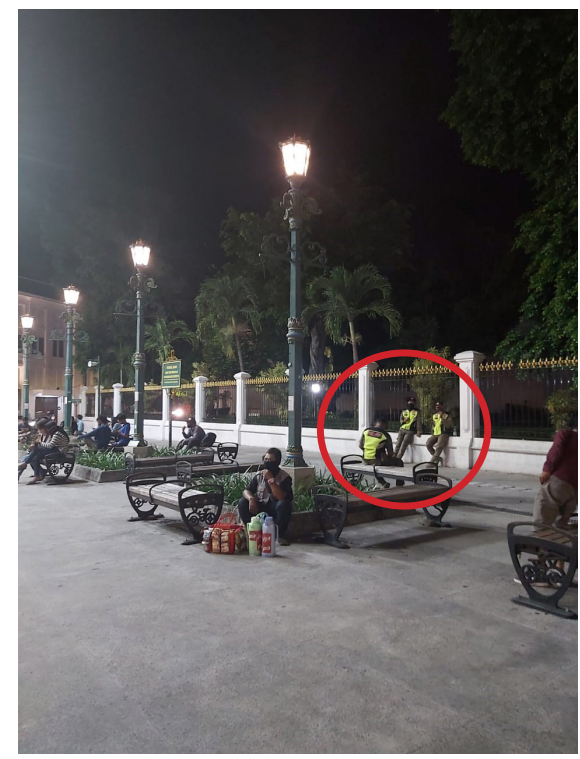


The Dynamics of Urban Public Space Perception in the New Normal Era

Yordan Kristanto Dewangga, Sita Yuliastuti Amijaya, Hoseo Viadolorosa
Figure 13. Zone areas that officers do not guard. Source: Dewangga Documentation, 2020.

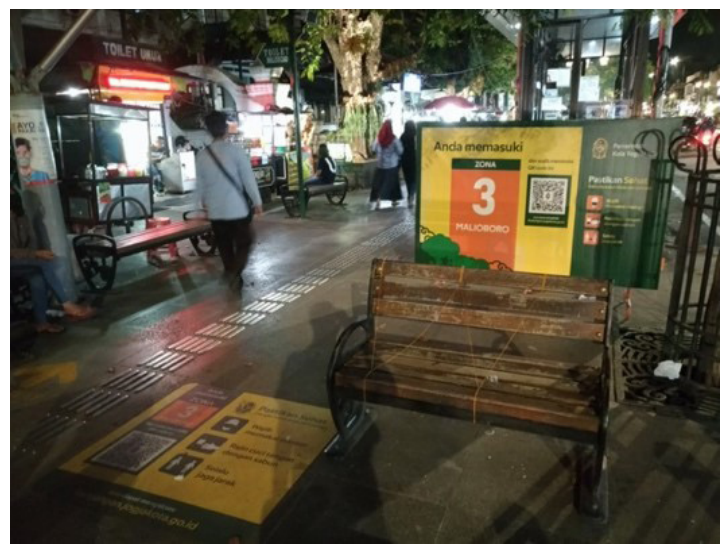

These conditions show that public awareness of maintaining social distancing in public spaces is still very low. People still have not adapted to new habits in the new normal era, especially in their activities and interactions in urban public spaces. Many people are still at a personal distance (Hall in Mulyana, 2005) when conducting social interactions in public spaces. In fact, security officers have not been able to remind visitors always to maintain social distance, at least $1.5-3$ meters. Various written and graphic health protocols have not been able to control community activities in urban public spaces.

\section{Conclusion}

The Malioboro street area is a public space in great demand not only by Yogyakarta residents but also from outside the Yogyakarta area. Even though activity in this area had decreased due to the coronavirus pandemic, slowly activity in this area began to return to the new normal era. The perception of urban public space as a place for various activities and social interactions identical to crowds and crowds does not experience a degradation of perception. What differentiates this time is a handwashing place and various written and verbal warnings made by security officers. This is done to comply with health protocols issued by the government, although sometimes there are still many people who do not care about these health protocols. The coronavirus pandemic has not reduced the perception of urban public spaces, especially Malioboro, as a pleasant place for most people to carry out various activities and social interactions.

\section{References}

Andersson, C. (2016). Public Space and the New Urban Agenda. The Journal of Public Space, 1(1), 5-10. Doi: https://doi. org/10.5204/jps.v1i1.4.

Gerungan, W. A. (2010). Psikologi sosial. Bandung: PT Refika Aditama.

Hantono, D. (2019). Kajian Perilaku pada Ruang Terbuka Publik. Journal NALARs, 18(1), 45-56. Doi: https://doi. org/10.24853/nalars.18.1.45-56

Honey-Roses, J., Anguelovski, I., Bohigas, J., Chireh, V. K., Mr., Daher, C., Konijnendijk, C., ... Nieuwenhuijsen, M. (2020). The Impact of COVID-19 on Public Space: A Review of the Emerging Questions. https://doi.org/10.31219/osf.io/rf7xa

Illiyin, D. F., and Idajati, H. (2015). FaktorFaktor yang Mempengaruhi Masyarakat dalam Penggunaan Ruang Terbuka Publik sebagai Fungsi Sosial di Gor Delta Sidoarjo Berdasarkan Prefernsi masyarakat. Journal TEKNIK ITS, 4(2), C-114-118. Doi: http://dx.doi. org/10.12962/j23373539.v4i2.11274

Manurung, P. (2018). Kota untuk semua. Ide penataan kota yang komprehensif. Yogyakarta: ANDI.

Menteri Kesehatan RI. (2020). Pedoman pembatasan sosial berskala besar dalam rangka percepatan penanganan corona virus disease 2019 (COVID-19). Jakarta: Dirjen Peraturan Perundang-Undangan Kementerian Hukum dan HAM RI. Accessed from https://covid19.go.id/p/ regulasi/permenkes-no-9-tahun-2020tentang-pedoman-psbb-dalam-rangkapercepatan-penanganan-covid-19

Mulyana, D. (2005). IImu komunikasi suatu pengantar. Bandung: PT Remaja.

Mulyandari, H. (2011). Pengantar arsitektur kota. Yogyakarta: C.V Andi Offset.

Nasution, A. D. and Zahrah, W. (2017). Public Open Space as Urban Architecture: Design and Public Life. IPTEK Journal of Proceedings Series, 3, 11-20. Accessed from http://iptek.its.ac.id/index.php/jps/ article/view/2481/2126

Nisa, A. F. and Haryanto, R. (2014). Kajian Keberadaan Wisata Belanja Malioboro terhadap Pertumbuhan Jasa Akomodasi di Jalan Sosrowijayan dan Jalan Dagen. Journal Teknik PWK, 3(4), 933948. Accessed from https://ejournal3. 
undip.ac.id/index.php/pwk/article/ view/6749/6810

Octarino, C. N., and Kristiadi, A. (2019). Karakteristik Iklim Mikro di Ruang Publik. Studi Kasus: Jalur Pedestrian Malioboro, Yogyakarta. Journal GRID, 1(2), 6-9. Accessed from http://www. unsa.ac.id/ejournal/index.php/grid/article/ view/336/204\#

Pratiwi, Y. (2016). Transformasi Fungsi Ruang Terbuka Publik di Perkotaan. Studi Kasus: Taman Pedestrian Kecamatan Tenggarong, Kabupaten Kutai Kartanegara, Kalimantan Timur. Journal NALARs, 15(1), 63-72. Doi: http://dx.doi. org/10.24853/nalars.15.1.63-72

Qomarun and Saifuddin, M. (2019). Pengaruh kondisi jalur pedestrian dan street furniture di jalan Malioboro terhadap kenyamanan ruang publik. Journal Sinektika, 30(1), 6-11. Accessed from http://journals.ums. ac.id/index.php/sinektika

Rahmiati, D. (2017). Kajian Elemen Pembentuk Ruang Kota pada Ruang Terbuka Publik Kota. Journal IKRA-ITH TEKNOLOGI, 1(2), 1-8. Accessed from https://journals.upi-yai.ac.id/index.php/ ikraith-teknologi/article/view/88/29

Rossini, F. and Nervino, E. (2019). City Branding and Public Space. The Journal of Public Space, 4(4), 61-82. https:// doi.org/https://doi.org/10.32891/jps. v4i4.1234

Schmidt, S. and Németh, J. (2010). Space, Place and the City: Emerging Research on Public Space Design and Planning', Journal of Urban Design, 15(4), 453 457. Doi: http://dx.doi.org/10.1080/135 74809.2010.502331

Wardhani, M.K. (2018). Titik Nol Kilometer Kota Yogyakarta sebagai Ruang Terbuka Publik Ditinjau dari Dimensi Fungsional, Sosial, dan Visual. Journal Planologi, 15(1), 1-16. Doi: http://dx.doi. org/10.30659/jpsa.v15i1.2739 